\title{
РЕШЕНИЯ И ПРАВОВЫЕ ПОЗИЦИИ КОНСТИТУЦИОННОГО СУДА РОССИЙСКОЙ ФЕДЕРАЦИИ: СУЩНОСТЬ, ВИДЫ И СООТНОШЕНИЕ'
}

\begin{abstract}
Аннотация: В статье предложен новый - дифференцированный - подход к определению сущности решений и правовых позиций Конституционного Суда Российской Федераиии. Решения Конституционного Суда в зависимости от наличия или отсутствия в них каких-либо выводов Суда предлагается делить на правоприменительные (не содержат выводов о норме права), нормативно-толковательные (раскрывают действительное содержание нормы права) и нормативно-корректирующие (изменяющие содержание нормы права вследствие обнаружения конституционного дефекта нормы права). Эти решения являются соответственно актами применения права, актами официального толкования права и источниками права. Отличными от решений Суда являются его правовые позиции, являющие выводами судами по поставленным переде ним вопросам. Решения и правовые позиции соотносятся как форма и содержание, иелое и часть. Правовые позиции Суда предлагается их делить на нормативные и доктринальные, отрииательные и положительные, постоянные и временные. Автором доказывается, что нормативные правовые позиции Суда, содержащиеся в нормативно-корректирующих решениях Суда, являются особым, специфичным источником права, который по кругу своих юридических свойств невозможно отнести ни к одному из известных науке источников права.

Abstract: The article provides a novel differentiated approach towards the nature of decisions and legal positions of the Constitutional Court of the Russian Federation. Depending on the presence of general conclusions author offers to distinguish among the decisions the normative enforcement (no conclusions regarding the status of legal norm); normative interpretation (conclusion on actual contents of the norm); normative correction (changing the contents of a legal norm due to a constitutional defect of a legal norm). Accordingly, these decisions serve as acts of legal enforcement, legal interpretation, and sources of law. The legal positions of the Court, which are conclusions of the court on the questions posed to them, are different from the decisions. Decisions and legal positions correlate as form and contents, part and whole. The author offers to distinguish normative and doctrinal legal positions, negative and positive legal positions, temporary and permanent legal positions. The author proves that the normative legal positions of the Court, as expressed in normatively correcting decisions of the Court serve as a specific source of law, which may not be included into any of the previously known groups of such sources, due to its unique legal qualities.

Ключевые слова: конституциионный суд, норма права, правовая позиция, коррекция норм права, толкование норм права, доктрина конституционного суда, источник права, форма права, прецедент, судебное право

Keywords: the Constitutional Court, legal norm, legal position, correcting legal norms, interpreting legal norms, doctrine of the Constitutional Court, source of law, form of law, precedent, judicial law.
\end{abstract}

\section{Введение}

Конституционный Суд Российской Федерации (далее - Конституционный Суд, Суд) функционирует более 22 лет, однако до настоящего времени вопрос природы принимаемых Судом решений в юридической науке остается одним из самых дискуссионных

\footnotetext{
${ }^{1}$ Статья выполнена при финансовой поддержке Российского гуманитарного научного фонда в рамках проекта проведения научных исследований № 12-33-01232 на тему «Формы взаимосвязи конституционного и уголовного судопроизводств в контексте доктрины судебного права».
}

в юридической науке2 2 Суть данного вопроса так или иначе сводится к признанию либо непризнанию этих решений и (или) содержащихся в них правовых позиций в качестве источника права; если же такое признание имеет место быть, то дискуссионным является вопрос о том к числу каких правовых актов они относятся. Точки зрения ученых по данному вопросу стали хрестоматийными: первые (О.Е. Кутафин,

\footnotetext{
2 Подробнее см.: Правовая природа решений Конституционного Суда РФ // Еникеев З.Д., Васильева Е.Г., Шагеева Р.М., Ежова Е.В. Вопросы уголовного судопроизводства в решениях Конституционного Суда Российской Федерации. М.: Юрайт, 2011. С. 67-93.
} 
DOI: 10.7256/1811-9018.2013.12.10169

При цитировании этой статьи сноска на доі обязательна

\section{Право и политика $12(167) \cdot 2013$}

В.С. Нерсесянц, В.В. Ершов, В.Н. Корнев) не признают решения Конституционного Суда источниками права, полагая, что они являются правовыми констатациями (О.Е. Кутафин), актами индивидуального судебного применения (В.В. Ершов, А.В. Корнев), либо же их нормативная сила вовсе противоречит принципу разделения властей (В.С. Нерсесянц). Другие же ученые признают за решениями Конституционного Суда нормативно-регулятивное значение, считая их нормативными или квазинормативными актами. Третьи же видят в решениях Конституционного Суда свойства судебных прецедентов, преюдициальных или преюстициарных актов. Несмотря на такое разнообразие мнение, определенность в данном вопросе все же отсутствует.

Понятие и юридической значение решений и правовых позиций Конституционного Суда, как в юридической науке, так и правоприменительной практике в настоящее время представляется крайне размытым: под ними понимаются как выводы Суда в резолютивной части его решения, так и в мотивировочной, как в постановлениях Суда, так и в его определениях. ${ }^{3}$ Такое разнообразие мнений фактически приводит к двум «полярным» ситуациям: в рамках первой все решения Конституционного Суда, будь-то постановления и (или) определения, представляются обязательными для всех субъектов права, как законодателя, так и правоприменителя, а во второй - высказанные как в постановлениях, так и в определениях правовые позиции игнорируются правоприменительной практикой.

Отсутствие определенности по данному вопросу как в доктрине, так и в законодательстве, как видится, порождает негативные последствия в правоприменительной практике. Так, по нашим подсчетам, в период с марта 2009 г. по октябрь 2013 г. Конституционным Судом было рассмотрено 2258 обращений граждан (в т.ч. жалоб на нарушение конституционных прав и свобод и ходатайств о разъяснении решений Суда), затрагивающих сферу уголовной юстиции (вопросы уголовного, уголовно-процессуального, уголовно-исполнительного и оперативно-розыскного законода-

\footnotetext{
${ }^{3}$ Борисова О.В. Правовые позиции Конституционного Суда Российской Федерации по налоговым спорам: Автореф. дис. .... канд. юрид. наук / 12.00.02, 12.00.14. - М., 2007. - С.15; Петрова Д.В. Правовые позиции Конституционного Суда Российской Федерации по вопросам его деятельности и конституционного судопроизводства: Автореф. дис. ... канд. юрид. наук / 12.00.02. - М., 2008. - С. 8, 17; Жучкова Е.В. Правовые позиции Конституционного Суда Российской Федерации по вопросам уголовного права и уголовного процесса: Автореф. дис. ... канд. юрид. наук / 12.00.02. - М., 2009. - С. 7; Алешкова И.А. Правовые позиции Конституционного Суда Российской Федерации: правовая природа и формы их осуществления // Российский судья. - 2013. - № 8. - С. 9.
}

тельства, а также отчасти законодательства о судоустройстве, адвокатуре и о прокуратуре). В принятии этих обращений к рассмотрению было отказано по причине их несоответствия требованиям Федерального конституционного закона от 21 июля 1994 года № 1-ФК3 «О Конституционном Суде Российской Федерации» ${ }^{4}$ (далее - Закон о Конституционном Суде), причем в 1296 определениях об отказе в принятии обращений к рассмотрению (57,39 \%) Суд, решая вопрос о возможности принятии обращения к своему рассмотрению, т.е. устанавливая наличие или отсутствие неопределенности в конституционности нормы права, подтвердил ранее сформулированные им правовые позиции по поставленному заявителем вопросу, а также отметил, что проверка соответствия закону и (или) правовой позиции Суда процессуальных действий и решений, имевших место в делах заявителей, не входит в его компетенцию. Такие выводы Суда в сопоставлении с материалами обращений заявителя, лишь косвенно, но все же свидетельствует о наличии правоприменительной ошибки в деле заявителя, обусловленной неучетом или даже игнорированием органами дознания, следствия, прокуратуры или судами общей юрисдикции в делах конкретных заявителей правовых позиций Конституционного Суда. Анализ этих обращений иллюстрирует и иную проблему - суды общей юрисдикции фактически отказываются применять так называемые определения Суда «с позитивным содержанием» (определения, которыми в принятии к рассмотрению в публичном слушании обращений отказывается, но у проверяемой отраслевой нормы права выявляется конституционноправовой смысл, как единственно возможное толкование этой нормы права, соответствующее Конституции Российской Федерации ${ }^{5}$ ), полагая, что такие решения, не имея форму постановлений Суда о признании норм не соответствующими Конституции, не имеют регулятивного значения. Практика принятия Судом «определений с позитивным содержанием» фактиче-

\footnotetext{
${ }^{4}$ Федеральный конституционный закон от 21 июля 1994 года № 1-ФКЗ «О Конституционном Суде Российской Федерации» (в редакции Федерального конституционного закона от 5 апреля 2013 года № 1-ФКЗ) // С3 РФ. 1994. № 13. Ст. 1447; 2001. № 7. Ст. 607; № 51. Ст. 4824; 2004. № 24. Ст. 2334. 2005. № 15. Ст. 1273; 2009. № 23. Ст. 2754; 2010. № 45. Ст. 5742; 2011. № 1. Ст. 1; 2012. № 53 (ч. 1). Ст. 7572; 2013. № 14. Ст. 1637.

${ }^{5}$ Подробнее об «определениях с позитивным содержанием» см.: Комментарий к статье 43 // Комментарий к Федеральному конституционному закону «О конституционном Суде Российской Федерации» / Под ред. Г.А. Гаджиева. М.: Норма; ИНФРА-М, 2012. С. 254-263 (автор комментария - С.Д. Князев).
} 
DOI: $10.7256 / 1811-9018.2013 .12 .10169$

При цитировании этой статьи сноска на dоі обязательна

Судебная власть

ски дезориентировала судебную практику в вопросе нормативного значения решений Суда, вследствие чего «суды не реагируют на определения Конституционного Суда с позитивным смыслом». ${ }^{6}$

Таким образом, определение природы и значения решений и правовых позиций Конституционного Суда имеет не только глубокое теоретическое значение, но и важную практическую значимость. Очевидно, что определение правовой природы решений и правовых позиций Конституционного Суда должно происходить иначе, чем это делалось в юридической науке ранее. При решении этого вопроса учеными во внимание не берется, что решения Суда различаются между собой поводами для своего вынесения, приемами и способами толкования норма права, а также аудиторией, которой они адресованы. Анализируя содержание конкретных решений Конституционного Суда, можно заметить, что не все решения Конституционного Суда обладают одинаковым содержанием, а потому нельзя утверждать о единстве правовой природы и их силы. Это обстоятельство создает предпосылки и основания к разработке нового подхода к определению сущности решений и правовых позиций Конституционного Суда.

Данный новый подход должен строиться на учете дифференциации правового содержания решений Конституционного Суда. Основанием к такой дифференциации решений Конституционного Суда являются степень и характер воздействия Суда на буквальное содержание отраслевых норм права, подверженных конституционному контролю. Наличие двух этих оснований делает классификацию решений и правовых позиций Конституционного Суда «сложной», а потому она происходит в два этапа. На первом этапе классификации определяется, содержатся ли в решении Суда какие-либо выводы Суда об оспоренной норме права (т.е. определять степень влияния), а на втором, к которому приступают только при наличии положительного ответа на первый вопрос, - каков результат воздействия решений Суда на проверенную норму (т.е. характер влияния). Отсюда большинство выносимых в порядке конституционного судопроизводства решений Суда7 ${ }^{7}$ можно условно разделить на три группы: правоприменительные, нормативно-толковательные и нормативно-корректирующие.

\footnotetext{
${ }^{6}$ Шиняева Н. Суды не реагируют на определения КС с позитивным смыслом. URL: http://pravo.ru/review/view/85691.

${ }^{7}$ Конституционный Суд, как известно, принимает решения не только по процессуальным вопросам (по форме заключения, постановления и определения), но и собственно решения по организационным вопросам. Данная разновидность решений представляется разновидностью правоприменительных актов.
}

\section{1. Правоприменительные решения Конституционного Суда}

Правоприменительные решения Конституционного Суда вычленяются при классификации решений Суда по первому основанию - факту наличия в решении каких-либо выводов Суда об оспоренных положениях отраслевого законодательства. Отсутствие в конкретных решениях Суда таких выводов позволяет отнести эти решения к числу правоприменительных. Следовательно, правоприменительные решения Суда не содержат каких-либо выводов об оспоренной норме права. Основанием к вынесению таких решений служит несоблюдение заявителем формальных, самых элементарных требований к жалобе, которые-то и препятствуют Конституционному Суду каким-либо образом комментировать оспоренное заявителем законоположение. При этом сам факт оспаривания законоположения применительно к данной ситуации нуждается в уточнении, поскольку доводы заявителя, раскрывающие неконституционность оспоренной нормы права (содержания закона) или же его толкования, придаваемого норме права правоприменительной практикой, фактически отсутствуют. Наиболее часто эти решения принимаются в связи в связи с жалобой гражданина, объединения граждан или иных лиц, которым предоставлено право обращения в Суд в порядке конкретного нормоконтроля, на нарушение конституционных прав и свобод положениями закона, примененными в конкретном судебном деле (далее - жалоба гражданина) и крайне редко в связи с запросом суда общей юрисдикции о проверке конституционности закона, подлежащего применению в конкретном судебном деле (далее - запрос суда), а равно в связи с запросами иных «профессиональных» участников конституционного судопроизводства, что обусловлено уровнем правовой компетентности данных заявителей.

Наиболее распространенными случаями (фактическими основаниями) вынесения таких решений являются следующие:

1) случаи, когда нарушение своих прав заявитель связывает не содержанием оспариваемой нормы, а с выводами в решениях судов по конкретным делам, что составляет наиболее типичную ситуацию в практике Конституционного Суда. Примерами таких решений могут служить определения Конституционного Суда от 26 мая 2011 г. № 653-О-О, от 22 марта 2012 г. № 612-О-О, от 19 июня 
DOI: $10.7256 / 1811-9018.2013 .12 .10169$

При цитировании этой статьи сноска на доі обязательна

\section{Право и политика $12(167) \cdot 2013$}

2012 г. № 1111-О, от 17 июля 2012 г. № 1380-О, от 24 января 2013 г. № 115-О, от 21 марта 2013 г. № 368-О ${ }^{8}$ и множество других. В таких жалобах формально ставится вопрос о неконституционности каких-либо положений законодательства, но не содержится каких-либо сколь существенных доводов о «порочности», дефектности этой нормы права. Иными словами, в таких жалобах формально оспаривая конституционность оспоренного положения закона, заявитель фактически ставит вопрос о проверке состоявшихся судебных решений по его делу, правильности толкования и применения оспоренных законоположений в его конкретном деле. Факт оспаривания нормы права в данном случае усматривается из резолютивной части жалобы; в остальных же частях жалобы доводы о неконституционности нормы не приводятся, а потому мало чем отличаются от апелляционных, кассационных и иных судебных жалоб, поскольку содержат описание обстоятельств производства по делу заявителя, или же его версию произошедших событий.

2) случаи, когда заявители, формально оспаривая конституционность закона, фактически ставят вопрос о внесении в действующее законодательство целесообразных с их точки зрения изменений и (или) дополнений. Примерами таких решений являются определения Конституционного Суда от 24 февраля 2011 г. № 168-O-О, от 22 марта 2011 г. № 372-О-О, от 21 апреля 2011 г. № 547-О-О, от 29 сентября 2011 г. № 1286-О-О, от 17 июля 2012 г. № 1380-О, от 24 декабря 2012 г. № 2258-О, от 25 февраля 2013 г. № 338-О, от 4 апреля 2013 г. № 660-О, от 28 мая 2013 г. № 861-О, от 16 июля 2013 г. № 1133-О9 и многие другие. Данная разновидность правоприменительных решений отличается большим вниманием заявителя к юридическому содержанию аргументации жалобы, однако «порок жалобы» кроется в несогласии заявителя с действующим законодательством, в следствие чего он предлагает редакцию, которая, по его мнению, будет отвечать, как положениям Конституции Российской Федерации, так и его личным представлениям о том, как эти конституционные положения должны быть реализованы в отраслевом законодательстве. Невозможность принятия (и, соответственно, удовлетворения) таких жалоб к рассмотрению объясняется рядом причин. С одной стороны, действует конституционное положение о том, что законы принимаются, изменяются,

\footnotetext{
${ }^{8}$ Официально не опубликованы.
${ }_{9}^{9}$ Официально не опубликованы.

${ }^{8}$ Официально не опубликованы.
${ }_{9}^{9}$ Официально не опубликованы.
}

дополняются и признаются утратившими силу законодательными (представительными) органами государственной власти (статья 71, пункты «а», «г», «о»и др., Конституции Российской Федерации), а потому в формально-юридическом смысле Конституционный Суд не может изменить текст закона или иного подконтрольного ему правового акта. Этому аргументу можно возразить, что Конституционный Суд все же может изменять содержание закона или его отдельных положений, например, в случае признания его неконституционным, что влечет утрату им силы (статья 125, часть 6, Конституции Российской Федерации). Тем не менее, такая коррекция закона не влечет изменения текста закона, а потому такая жалоба не может быть принята к рассмотрению (если она не содержит содержательных доводов о неконституционности закона, которые могут быть оценены Судом). С другой стороны, заявители таких жалоб - при условии конституционности отраслевого законодательства - фактически предлагают Конституционному Суду целесообразность нормы, а потому переводят вопрос из плоскости права в плоскость политики, в которую Конституционный Суд, как неоднократно отмечал в своих решениях, не вторгается, ибо это составляет исключительную прерогативу федерального законодателя.

3) случаи, когда заявителем не представлены документы, подтверждающие применение в его деле оспоренного положения закона в указанном в обращении аспекте. Такие основания содержатся в достаточно большом количестве определений Суда об отказе в принятии обращения к рассмотрению (практически, в каждом втором), примерами таких решений могут быть определения от 22 ноября 2012 г. № 2009-О, № 2016-О, № 2165-О, № 2194-О и № 2045-О, от 24 декабря 2012 г. № 2262-О, от 24 января 2013 г. № 9-О, от 25 февраля 2013 г. № 183-О, от 23 апреля 2013 г. № 546-О, № 613-О, № 617-О, № 619-О и № 652-О, от 28 мая 2013 г. № 729-О и № 784-О, от 17 июня 2013 г. № 1018-О, от 16 июля

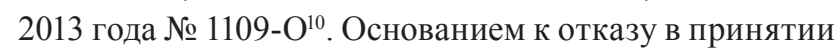
обращений к рассмотрению является несоблюдение заявителем такого критерия допустимости обращений, как применение закона оспариваемого закона в деле заявителя (статьи 3, 96 и 97 Закона о Конституционном Суде), который придает жалобе характер поданной в порядке конкретного нормоконтроля. В отсутствие применения закона Конституционному Суду фактически предлагается оценить закон в абстрактном порядке,

\footnotetext{
${ }^{10}$ Официально не опубликованы.
} 
т.е. фактически оценить конституционность толкования оспоренного законоположения конкретными заявителями.

Иные основания принятия правоприменительных решений менее распространены и более конкретны. К примеру, к ним относятся случаи неисполнения заявителями иных требований Закона о Конституционном Суде, предъявляемых к обращениях (статьи 36-39, 96-97, 101-102). Например, Конституционный Суд может отказать в жалобы гражданина, если адвокатом, действующим в интересах заявителя, не подтверждены свои полномочия соответствующей доверенностью (от 23 апреля 2013 г. № 556-О, от 16 июля 2013 г. № 1121-О и № 1136-О밍.

Правоприменительные решения Суда являются актами применения Закона о Конституционном Суде, а потому вопрос об их каком-либо нормативном значении не может ставиться a priori. Данные решения обладают свойством обязательности, распространяющим свой действие на Суд и заявителя. Такого рода решения всегда имеют форму определений об отказе в принятии жалобы (ходатайства о разъяснении решения Суда) к рассмотрению. Их легко выявить в общей массе решений Суда, поскольку они не велики по объему, а их мотивировочная часть содержит соответствующие «фразы-маркеры».

\section{2. Нормативно-толковательные решения Конституционного Суда}

В случае же наличия в решениях Конституционного Суда каких-либо выводов о норме права мы наблюдаем решения, условно именуемые нормативными, поскольку их главное свойство заключается в наличии в этих решениях так или иначе высказанного Судом мнения об отраслевых нормах права, конституционность которых оспорена заявителем. Эти решения Суда различаются содержанием высказанных выводов Суда: если решение не изменяет буквальное содержание нормы права или смысл, придаваемой ей правоприменительной практикой, мы имеем дело с нормативно-толковательным решением, а если выводы Суда обратные - с нормативно-корректирующим.

Нормативно-толковательные решения, содержат выводы Конституционного Суда о норме права, не изменяющие её содержания. Эти выводы Конституционного Суда могут быть результатом разнообразного толкования норм права, зависящего

\footnotetext{
${ }^{11}$ Официально не опубликованы.
}

от степени формальной определенности (ясности и четкости формулирования) законодательного текста, характера поставленного заявителем вопроса и степени сложности правоприменительной ситуации заявителя. Поэтому наиболее часто, как показывает практика конституционного правосудия, Суд использует приемы буквального, системного (отраслевого или межотраслевого), целевого толкования нормы. Толкование в данном случае преследует достижение двух целей: установление содержания проверяемой им нормы права и объяснение её конституционности, в силу чего данное толкование всегда является изъяснительным.

Буквальное толкование нормы права, пожалуй, самый простой способ толкования из числа используемых Судом и самый распространенный. Распространенность этого вида толкования обусловлена правовой безграмотностью большей части обращающихся в Конституционный Суд лиц. Например, заявитель ставит вопрос о том, что норма права нарушает его конституционные права, поскольку предписывает определенный - имеющий место в его деле - вариант её применения, предполагающий например, определенный порядок действий суда или принятие к нему (заявителю) определенных мер воздействия. Буквально же толкование нормы права ясно и четко констатирует, что применение оспоренного законоположения к такому положению вещей, о котором утверждает заявитель, приводить не может. Следовательно, данная жалоба, как не отвечающая критериям допустимости обращений в Конституционный Суд, не подлежит принятию к рассмотрению (например, Определение Конституционного Суда от 25 февраля 2013 г. № 314-О'ㄹ).

Системное отраслевое толкование представляет более сложный способ, поскольку итоговый вывод Конституционного Суда формируется путем сопоставления двух и более норм одной отрасли права (например, общей и особенности частей данной отрасли права), поскольку из одной нормы права искомый вывод сделать нельзя либо на конкретную ситуацию распространяют своё действие обе эти нормы.

Системное межотраслевое толкование являет собой более сложный вид, поскольку толкованию подлежат нормы разных отраслей права по смежному вопросу (например, Определение Конституционного Суда от 17 июля 2012 г. № 1335-Оㅜㄹ).

Целевое толкование есть толкование нормы права, даваемое исходя из цели её принятия. Данный вид наи-

\footnotetext{
${ }^{12}$ Официально не опубликовано.

${ }^{13}$ Официально не опубликовано.
} 


\section{Право и политика 12 (167) • 2013}

более «искусный (изящный)» в практике Суда, ибо он показывает место «ординарной» отраслевой нормы в системе данной отрасли и отражает то, как эта норма «работает» (или, наоборот, «не работает») на достижение этой цели, на функционирование институтов этой отрасли права.

Особенность данного вида решений состоит в том, что в них содержится, как правило, развернутое толкование отраслевых норм права, которые были оспорены заявителем. Содержание конституционных норм права в данных решениях практически не раскрывается или раскрывается на основе уже выработанных правовых позиций Суда. Это обуславливается, скорее всего тем, что вопрос о наличии (отсутствии) неопределенности в конституционности оспоренного законоположения разрешается через установление действительного содержания оспоренных законоположений и соотнесением данного содержания права с конституционным текстом или производными от него позициями Конституционного Суда.

Нормативно-толковательные решения Суда облекаются в форму определений об отказе в принятии жалобы гражданина (запроса суда) к рассмотрению в заседании Суда, реже - в форме определений о прекращении производства по делу. Результат толкования норм права в данных решениях содержится в мотивировочной части решений, поскольку резолютивная часть этих решений, как правило, лишена каких-либо выводов о норме права.

Такие решения Конституционного Суда не имеют нормативного значения, поскольку после их вынесения норма права не претерпевает изменения, а потому сохраняется прежнее правовое регулирование. Признание и применение таких решений в качестве самостоятельных источников права не дало бы правоприменителю ничего более, чем предусмотрено законом для соответствующих материальных или процессуальных правоотношений. Следовательно, эти решения по своей юридической природе являются актами официального толкования норм права. Такие решения могут использоваться в судебной практике как средство установления судами действительного содержания юридических норм перед их применением в конкретном деле.

Поскольку эти решения являются актами толкования права, то период их действия, или период «юридической актуальности», ограничен периодом действия толкуемой нормы права. Отсюда, если изменяются какие-либо законоположения, истолкованные Судом, а новое правовое регулирование позволяет заявителям ставить вопросы о его неконституционности, то ранее прежние правовые позиции Суда по данному вопросу уже не могут связывать Суд в принятии решения в вопросе конституционности нового правового регулирования.

\section{3. Нормативно-корректирующие решения Конституционного Суда}

Нормативно-корректирующие решения отличаются тем, что в них норма или часть нормы права корректируется Конституционным Судом. Единственной причиной изменения Судом нормы права является установление её противоречия Конституции, т.е. её конституционного дефекта.

\section{1. Конституционные дефекты норм права: по-} нятие и виды

Российское право по своей структуре является иерархизированной системой норм права различной юридической силы. Венчает «пирамиду российского права» Конституция, а на каждой следующей ступени этой «лестницы права» зиждутся источники права меньшей юридической силы. Конституционные нормы, будучи самыми всеобъемлющими по своему предмету и самыми общими по своему формулированию, должны быть обеспечены и конкретизированы в текущем законодательстве. Обеспечить это должен федеральный законодатель путем принятия соответствующего правового регулирования, а также по его уполномочию - иные государственные органы, как правило, органы исполнительной власти. Средством контроля за тем, как федеральный законодатель реализует и воплощает конституционные предписания в своей юриспруденции призван Конституционный Суд путем рассмотрения в порядке абстрактного, так и конкретного (инцидентного) нормоконтроля. Россия, если не принадлежа романогерманской правовой семье, то имея с ней очень близкую связь, в 1990-ые годы восприняла австро-немецкие идеи конституционного контроля ${ }^{14}$, который должен быть централизованным и сосредоточенным в руках одного органа - Конституционного Суда, обеспечивающего своеобразный «стандарт конституционности».

Противоречие отраслевых норм права конституционным нормам следует рассматривать как конституционный дефект отраслевой нормы права. Собственно, к

\footnotetext{
${ }^{14}$ Одной из таких идей были идеи Ганса Кельзена, изложенные, в том числе, в работе «Судебная гарантия Конституции (конституционная юстиция)» (1928) Перевод этой работы с небольшими сокращениями, выполненный Д.В. Даниленко, см.: Кельзен Г. Судебная гарантия Конституции (конституционная юстиция) // Право и политика. - 2006. - № 8. - С. 5-14; № 9. - С. 5-18.
} 
оценке текущего законодательства на предмет наличия в нем конституционных дефектов и сводится деятельность Конституционного Суда.

Основанием к выделению конституционных дефектов служит статья 86 Закона о Конституционном Суде, определяющая пределы проверки конституционности нормативных правовых актов Конституционным Судом, а также отчасти статья 74 того же Закона, касающаяся характеристик предмета рассмотрения Конституционного Суда. Конституционные дефекты норм права разнообразны, однако к числу наиболее распространенных можно отнести следующие:

а) конституцчионные дефекты норм права по их буквальному содержанию. Дефект по буквальному содержанию имеет место тогда, когда текстуальное выражение нормы права очевидно противоречит конституционным положениям. Тем самым Конституционный Суд оценивает лишь «волю законодателя», изложенную в законе. Основанием к выделению этой разновидности дефектов является часть вторая статьи 74 и пункт 1 части первой статьи 86 Закона о Конституционном Суде, в силу которых Суд устанавливает соответствие Конституции нормативных актов органов государственной власти и договоров между ними по буквальному содержанию норм.

Такого рода конституционные дефекты были распространены в первые годы практики конституционного правосудия, в настоящее время их количество уменьшилось за счет распространения дефектов второго вида.

Примером такого конституционного дефекта является пункт 100 Регламента Правительства Российской Федерации, согласно которому законопроект, поступивший на заключение в Правительство Российской Федерации без финансово-экономического обоснования и иных необходимых материалов, возвращается Аппаратом Правительства субъекту права законодательной инициативы с сообщением причин, по которым невозможно представить заключение (Постановление Конституционного Суда от 29 ноября 2006 года № 9-П ${ }^{15}$ ).

Иной, усложненный, пример, иллюстрирующее конституционный дефект, закрепленный в нескольких статьях закона: правовое регулирование, содержавшееся в статье 3 , пункте 6 части первой статьи 108, части первой, второй и пункте 1 части третьей статьи 109 , статьях 112 и 115, пункте 4 части первой статьи 232

\footnotetext{
${ }^{15}$ Постановление Конституционного Суда Российской Федерации от 29 ноября 2006 года № 9-П по делу о проверке конституционности пункта 100 Регламента Правительства Российской Федерации // Собрание законодательства Российской Федерации. - 2006. - № 50 (11 декабря). - Ст. 5371.
}

и части первой, второй и четвертой статьи 256 УПК РСФСР, в той части, в какой они предусматривали или допускали полномочия суда возбуждать уголовное дело, в том числе в отношении нового лица, и применять к нему меру пресечения. Данный конституционный дефект был устранен Постановлением Конституционного Суда от 14 января 2000 года № 1-П ${ }^{16}$.

б) конституцчионные дефекты норм права по их смыслу, придаваемому им правоприменительной практикой. Данная разновидность конституционных дефектов, имея те же нормативные основания к выделению, отличается от первой тем, что в силу характера формулирования отраслевой нормы права, допускающей разнообразные варианты её толкования и применения, Конституционный Суд оценивает не только волю законодателя, но и толкование этого законоположения в судебной практике - судом общей или арбитражной юрисдикции при рассмотрении конкретного дела. Этот вид дефектов чаще других распространен в практике конституционного правосудия.

Понятие правоприменительной практики в данном случае наполняется различным содержанием: ею может выступать судебное толкование закона, поднятое до уровня постановления Пленума Верховного Суда Российской Федерации или Пленума Высшего Арбитражного Суда Российской Федерации, так и толкование закона судом, рассматривающим конкретное уголовное, гражданское или административное дело.

Примером первого может служить Постановление от 13 июля 2010 г. № 15-П'17, в котором Суд признал неконституционными взаимосвязанные положения части первой статьи 188 УК Российской Федерации, части 1 статьи 16.2 и части 2 статьи 27.11 КоАП Российской Федерации в той мере, в какой данные положения в системе действующего правового регулирования

\footnotetext{
${ }^{16}$ Постановление Конституционного Суда Российской Федерации от 14 января 2000 года № 1-П по делу о проверке конституционности отдельных положений Уголовно-процессуального кодекса РСФСР, регулирующих полномочия суда по возбуждению уголовного дела, в связи с жалобой гражданки И.П. Смирновой и запросом Верховного Суда Российской Федерации // Собрание законодательства Российской Федерации. - 2000. - № 5 (31 января). - Ст. 611.

17 Постановление Конституционного Суда Российской Федерации от 13 июля 2010 года № $15-П$ по делу о проверке конституционности положений части первой статьи 188 Уголовного кодекса Российской Федерации, части 4 статьи 4.5 , части 1 статьи 16.2 и части 2 статьи 27.11 Кодекса Российской Федерации об административных правонарушениях в связи с жалобами граждан В.В. Баталова, Л.Н. Валуевой, З.Я. Ганиевой, О.А. Красной и И.В. Эпова // Собрание законодательства Российской Федерации. - 2010. - № 29 (19 июля). - Ст. 3983.
} 
DOI: $10.7256 / 1811-9018.2013 .12 .10169$

При цитировании этой статьи сноска на ооі обязательна

\section{Право и политика $12(167) \cdot 2013$}

позволяют при оценке стоимости товара, перемещаемого физическим лицом через таможенную границу Российской Федерации и предназначенного для личного пользования, в целях определения наличия состава преступления (контрабанда) или административного правонарушения (недекларирование товаров), а также исчисления размера административного штрафа использовать его рыночную стоимость на территории Российской Федерации и в стоимость товара для указанных целей включать стоимость всего перемещаемого товара, в том числе и ту ее часть, которая разрешена к ввозу без письменного декларирования и уплаты таможенных пошлин, налогов. Толкование данных норм, связывающих определение размера контрабанды с рыночной стоимостью товаров, ввезенных на территорию Российской Федерации, вытекало из абзаца третьего пункта 3 Постановления Пленума Верховного Суда Российской Федерации от 27 мая 2008 г. № 6 «О судебной практике по делам о контрабанде» ${ }^{18}$. В связи с принятием Постановления Конституционного Суда от 13 июля 2010 г. № 15-П Пленум Верховного Суда своим постановлением от 28 сентября 2010 г. № $23^{19}$ исключил указанный абзац.

Примером второго случая, сводящегося к проверке конституционности закона в его истолковании, данном в конкретных судебных решениях, может служить Постановление Конституционного Суда от 28 февраля 2012 г. № 4-П²0, в котором Суд фактически оценил конституционность толкования пункта $1^{1}$ статьи 12 Федерального закона «Об общих принципах организации законодательных (представительных) и исполнительных органов государственной власти субъектов Российской Федерации», данного Президиумом Верховного Суда Чувашской Республики и Судебной

\footnotetext{
18 Постановление Пленума Верховного Суда Российской Федерации от 27 мая 2008 года № 6 «О судебной практике по делам о контрабанде» // Бюллетень Верховного Суда Российской Федерации. -2008 . - № 8 .

19 Постановление Пленума Верховного Суда Российской Федерации от 28 августа 2010 года № 23 «О внесении изменения в Постановление Пленума Верховного Суда Российской Федерации от 27 мая 2008 г. № 6 «О судебной практике по делам о контрабанде» // Бюллетень Верховного Суда Российской Федерации. - 2010. - № 11.

${ }^{20}$ Постановление Конституционного Суда Российской Федерации от 28 февраля 2012 года № 4-П по делу о проверке конституционности пункта $1^{1}$ статьи 12 Федерального закона «Об общих принципах организации законодательных (представительных) и исполнительных органов государственной власти субъектов Российской Федерации» в связи с жалобой гражданки Т.И. Романовой // Собрание законодательства Российской Федерации. - 2012. № 11 (12 марта). - Ст. 1365.
}

коллегией по гражданским делам Верховного Суда Российской Федерации.

в) конституционные дефекты норм права по форме содержащих их источников. Данная разновидность подлежи выделению на основе пункта 2 части первой статьи 86 Закона о Конституционном Суде, определяющего возможность проверки конституционности нормативных актов по форме. Данный вид конституционных дефектов крайне редко встречается в практике, тем не менее, примеры таким дефектам есть. Самый яркий - дефект положений ГПК, констатированный Судом в Постановлении от 27 января 2004 г. № 1-П²1. Гражданский процессуальный кодекс Российской Федерации, определяющий правила гражданского судопроизводства в судах общей юрисдикции, в т.ч. устанавливающий подсудность Верховному Суду Российской Федерации дел об оспаривании постановлений Правительства Российской Федерации, принят в форме федерального закона. В то же время, статья 128 (часть 3) Конституции предписывает, что полномочия, порядок образования и деятельности федеральных судов, в т.ч. Верховного Суда Российской Федерации, определяются федеральным конституционным законом. Следовательно, полномочия Верховного Суда Российской Федерации по рассмотрению дел указанной категории должны быть закреплены в федеральном конституционном законе. Конституционный Суд воздержался от признания положений ГПК неконституционными по форме нормативного правового акта (пункт 3 резолютивной части), однако в мотивировочной части данный дефект весьма подробно описан.

Перечень видов конституционных дефектов может продолжен, например за счет включения в него конституционных дефектов норм права по порядку принятия содержащих их источников. Данный вид дефектов выделяется на основе пункта 3 части первой статьи 86 Закона о Конституционном Суде; однако «иллюстрация» данному дефекту в практике Суда отсутствует.

\section{2. Способы устранения конституционных де- фектов норм права}

Выявленный конституционный дефект, как правило, должен быть устранен. Закон о Конституционном Суде считает единственным способом устранения

\footnotetext{
${ }^{21}$ Постановление Конституционного Суда Российской Федерации от 27 января 2004 года № 1-П по делу о проверке конституционности отдельных положений пункта 2 части первой статьи 27 , частей первой, второй и четвертой статьи 251 , частей второй и третьей статьи 253 Гражданского процессуального кодекса Российской Федерации в связи с запросом Правительства Российской Федерации // Собрание законодательства Российской Федерации. - 2004. № 5 (2 февраля). - Ст. 403.
} 
конституционных дефектов норм права признание нормы неконституционной в постановлении Конституционного Суда (статьи 87, 91, 100 и 104). Тем не менее, практика нормокоррекции куда богаче. Рассмотрим её на примере дел из сферы уголовной юстиции. Так, по нашим подсчетам, в 1995-20132 гг. в практике по вопросам уголовной юстиции Суд использовал разные способы устранения конституционных дефектов норм права:

1) признание отраслевой нормы неконституционной в постановлениях Суда, т.е. их автоматическая дисквалификация из соответствующей отрасли права, - данным способом Суд воспользовался в 41 постановлении;

2) выявление конституционно-правового смысла отраслевой нормы в постановлении Суда (17 решений),

2) выявление конституционно-правового смысла отраслевой нормы в определении Суда об отказе в принятии обращения к рассмотрению (26 решений), а равно в определении о прекращении производства по делу (14 решений),

3) признание отраслевой нормы de facto неконституционной в определении об отказе в принятии обращения к рассмотрению (24 решения).

История расширения способов нормокоррекции в практике российского конституционного правосудия известна: Определением от 27 июня 2000 г. № 92-О 22 Суд породил практику фактического признания неконституционными отраслевых законоположений путем принятия определения об отказе в принятии обращения к рассмотрению на том основании, что оспариваемые этим заявителем нормы аналогичны нормам, ранее уже признанным Конституционным Судом неконституционными; в силу этого проведение публичного слушания, которое имеет место при принятии обращения к рассмотрению. Подобная практика позволила ряду ученых делать далеко не комплементарные оценки в адрес Суда ${ }^{23}$, а в конечном счете - выборочное приме-

22 Определение Конституционного Суда Российской Федерации от 27 июня 2000 года № 92-О по запросу группы депутатов Государственной Думы о проверке соответствия Конституции Российской Федерации отдельных положений Конституций Республики Адыгея, Республики Башкортостан, Республики Ингушетия, Республики Коми, Республики Северная Осетия - Алания и Республики Татарстан // Собрание законодательства Российской Федерации. - 2000. - № 29 (17 июля). - Ст. 3117.

${ }^{23}$ См., напр., Сасов К.A. Споры о конституционности налоговых законов6 полномочия Конституционного Суда Российской Федерации: Монография / Под ред. М.Ф. Ивлевой. - М.: Статут, 2006. - С. 149; Ганичева E.C. Концепция развития правового регулирования конституционного судопроизводства // Концепции развития российского законодательства / Под ред. Т.Я. Хабриевой и Ю.А. Тихомирова. М.: Эксмо, 2010. С. 602-603. нение или даже их игнорирование в судебной практике общих и арбитражных судов ${ }^{24}$.

Представляется, что круг способов нормокоррекции должен быть известен всем субъектам права. Такая осведомленность необходима для обеспечения восприятия решений Суда в правоприменительной практике. Законом о Конституционном Суде Суд задуман как «негативный законодатель», призванный устранять конституционные дефекты норм права. Следовательно, коррекция нормы права должна происходить путем выявления Конституционным Судом её конституционного дефекта в постановлениях Конституционного Суда путем признания нормы неконституционной. Такой способ нормокоррекции влечет их автоматическую дисквалификацию из отрасли права неконституционных норм и (или) их толкований. Использованию только такого способа коррекции норм способствует введенное статьей $47^{1}$ Закона о Конституционном Суде письменное производство.

Иные, практически уже не используемые Судом способы устранения конституционного дефекта, - выявление конституционно-правового смысла нормы, исключающего иные её толкования, - независимо от фиксации в Законе о Конституционном Суде, как видится, не обеспечивают в полной мере свою цель, являются неэффективными, поскольку без изменения текста закона, как показывает судебная практика и обращения граждан в Суд, остается больша́я вероятность продолжения применения нормы в неконституционном смысле.

\section{3. Правовая природа нормативно-корректиру- ющихх решений}

С учреждением Конституционного Суда российская юридическая наука получила еще одну неиссякаемую тему для рассуждений, еще одну научную дискуссию - о правовой природе решений Суда. Высказанные в рамках данной дискуссии аргументы, как отмечалось ранее, не читывали юридическое содержание решений. Если с природой правоприменительных и нормативнотолковательных решений особые дискуссии не возникли, то природа нормативно-корректирующих решений требует своего подробного обсуждения.

Следуя принципу бритвы Оккамы, следует определить, можно ли отнести правовые позиции к числу известных современной теории права источников права (нормативный правовой акт, судебный прецедент, правовой обычай, договор, доктрина), или же иных

\footnotetext{
${ }^{24}$ Шиняева Н. Суды не реагируют на определения КС с позитивным смыслом. URL: http://pravo.ru/review/view/85691.
} 


\section{Право и политика 12 (167) • 2013}

правых актов (например, в литературе предлагается считать решения Суда правоприменительными, интерпретационными, преюдициальными и даже преюстициарными актами).

От нормативного правового акта решения Конституционного Суда отличает их форма и процедура принятия: по своей форме решение Суда является судебным решением и отличается от формы закона (наиболее типичного нормативного правового акта); если закон принимается по парламентской процедуре, т.е. по процедуре, направленной на поиск и выработку единого решения, т.е. «неконфликтной» процедуре, то судебная процедура предполагает разрешение спора между сторонами по поводу конституционности закона.

От правового обычая решение Конституционного Суда также отличается своей письменной формой, в то время когда обычай отличается от писанного права отсутствием своего текстуального закрепления.

От договора решение Суда отличается формальным отсутствием договаривающихся сторон, согласование воль которых и образует содержание договора. Решение Суда есть отражение не сколько воли, а логических выводов Суда по поставленному перед ним заявителем вопросу.

Наиболее дискуссионным является различение и (или) отождествлении решений Конституционного Суда и судебных прецедентов. Судебный прецедент в современной юридической науке, как исходя из анализа российской судебной практики, так и анализа зарубежной практики, понимается скорее, как прецедент толкования, т.е. такое судебное решение, которое содержит толкование законов, как правило, допускающих двоякое или иное другое неоднозначное толкование, и в котором делается мотивированный выбор способа разрешения дела. Самый яркий пример такого судебного прецедента являются постановления Президиума Высшего Арбитражного Суда Российской Федерации, чья прецедентная практика признана конституционной (Постановление Конституционного Суда от 21 января 2010 г. № 1-П²5). При таком подходе решения Конституционного Суда отличаются от судебных пре-

\footnotetext{
${ }^{25}$ Постановление Конституционного Суда Российской Федерации от 21 января 2010 года № 1-П по делу о проверке конституционности положений части 4 статьи 170, пункта 1 статьи 311 и части 1 статьи 312 Арбитражного процессуального кодекса Российской Федерации в связи с жалобами закрытого акционерного общества «Производственное объединение «Берег», открытых акционерных обществ «Карболит», «Завод «Микропровод» и «Научно-производственное предприятие «Респиратор» // Собрание законодательства Российской Федерации. - 2010. - № 6 (8 февраля). - Ст. 699.
}

цедентов возможностью изменения Конституционным Судом нормативной ткани закона, т.е. его коррекции вследствие обнаружения конституционного дефекта, в то время, когда обычный суд такой возможности по действующему законодательству лишен.

Не охватываются свойства решений Суда и такими понятиями как правоприменительный или интерпретационный акт. И правоприменение и толкование являются составными частями конституционного судопроизводства: в первом случае Конституционный Суд применяет для разрешения по существу Конституцию, а во втором - Суд толкует и конституционные и отраслевые нормы, поскольку толкование норм права является для Суда единственным способом установления их содержания.

Эти суждения подтверждают, что решения Суда и его правовые позиции нельзя отнести ни к одному из известных доктрине источников права.

Исходным юридическим свойством решений Суда должно являться свойство, выводимое из статьи 125 (часть 6) Конституции, согласно которой акты или их отдельные положения, признанные неконституционными, утрачивают силу. Это положение отражает характер реального и эффективного контроля Конституционного Суда за конституционностью законодательство. Иной подход - считать решение Суда лишь констатацией неконституционности нормы права, требующей еще отмены этого положения законодателем, сводило бы на нет эффективность конституционного контроля. Это свойство и отражает статус Конституционного Суда как негативного законодателя; его можно условно определить как корректирующее воздействие решений Суда на проверяемую отраслевую норму права и привнесение новации в отраслевое регулирование.

Также у решений Конституционного Суда усматриваются такие свойства:

1) результат толкования и Конституции и отраслевой нормы;

2) доктринальность (научность); этим качеством решения Конституционного Суда качественно отличаются от федерального и иного другого нормотворчества;

4) окончательность;

5) непосредственное действие;

6) обязательность для неопределенного круга лиц;

7) преюдициальность;

8) непреодолимость другими субъектами права.

Вышеприведенные свойства, которые так или иначе ранее выделялись в науке, свидетельствует о нормативной природе решений Суда. Нормативность решений Суда в данном аспекте следует рассматривать 
не как появление в нем новых норм права, а как изменение - путем признания неконституционным - уже существующего правового регулирования. Данный вывод справедлив на большинство случаев в конституционно-судебной практике, за исключением случаев проверки пробела и запрета. В первом случае Суд констатирует обусловленную Конституцией необходимость существования правового регулирования, а во втором случае - путем признания неконституционным запрета, мы фактически получаем позитивное регулирование. Вопрос же о том, кто должен текстуально восполнять образующиеся лакуны решается двумя способами: в рамках первого Конституционный Суд дает поручение федеральному законодателю установить правовое регулирование, а в других - непосредственно действует Конституция, причем в истолковании, данном Конституционным Судом, что в результате делает решение Суда de facto актом прямого регулирования общественных отношений.

\section{4. Правовые позиции Конституционного Суда}

Характеризуя только нормативно-корректирующие решения Суда, мы не можем отметить, что в нем содержатся различного рода выводы Суда, которые в литературе предлагается именовать правовыми позициями. Между тем, не все такие суждения однородны, а различаются между собой. Отсюда правовые позиции можно разделить на две группы: нормативные и доктринальные. Первые являются основаниями к корректировке норм права, эти правовые позиции раскрывают содержание конституционного дефекта, а также есть системное толкование конституционных норм. Вторые - являются промежуточными выводами Суда, ведущими его к итоговому выводу.

В идеальном варианте развития конституционного судопроизводства нормативные правовые позиции должны содержаться лишь в резолютивной части нормативно-корректирующего решения, а доктринальные -в мотивировочной части. Иными словами: цепь доктринальных позиций должна вести к одной или нескольким нормативным.

Оценивая природу нормативных правовых позиций Конституционного Суда, мы должны соотнести решения и правовые позиции Суда. Эти явления соотносятся, с одной стороны, как форма и содержание, а с другой - как часть и целое, поскольку не весь объем решения составляют его правовые позиции.

Анализируя природу нормативных правовых позиций, которые по своим свойствам аналогичны норма- тивно-корректирующим решениям, можно констатировать, что в российской правовой системе существует самостоятельный, новый и уникальный источник права - нормативные правовые позиции Конституционного Суда (содержание источника права), закрепленные в нормативно-корректирующих решениях Суда (его форма).

В иерархии источников права правовые позиции Суда занимают «подконституционное» место, т.е. следуют за Конституцией и Законами о поправках к ней; они производны от конституционного текста и, в отличие от постановлений Суда о толковании Конституции, не устраняют в нем неопределенности, а равно иным образом не прибавляют к нему нового содержания.

Отсюда нормативные правовые позиции можно определить как представления Конституционного Суда о том, как должны быть реализованы конституционные предписания в отраслевом законодательстве. Отсюда нормативные правовые позиции отражают как содержание и дух конституционного текста, так и способ вживления этого текста в ткань отраслевого права.

Доктринальные правовые позиции не имеют нормативного значения, но они отражают представления Суда о каком-либо правовом институте (например, сущности или содержании какого-либо конституционного права личности, о цели принятия закона и проч.). Сформулировав их в одном решении, Конституционный Суд может опираться на них в своих других решения, в которых будут сформулированы другие нормативные позиции.

В научной литературе и правоприменительной практике является дискуссионной проблема универсализации позиций Конституционного Суда правоприменительными органами, которая, по мнению ряда авторов, допустима. Правоприменитель не может из нескольких доктринальных или нормативных позиций формулировать свою, не укладывающуюся в имеющееся законодательное регулирование. Данное явление не только не укладывается в систему разделения властей, но и имеет, пожалуй, некий коррупционный аспект. Фактически правоприменитель будет подменять Конституционный Суд в то время, когда такая «комбинация» позиций Суда или позиций Суда и положений закона еще не формулировалась Конституционным Судом либо не проверялась им на конституционность.

Кроме того, правовые позиции Конституционного Суда можно делить еще по нескольким основаниям, носящим вспомогательный характер, на:

- по способу формулирования - на отрицательные и положительные: первые содержат вывод о недопустимости наличия в правовой системе государстве 
DOI: 10.7256/1811-9018.2013.12.10169

При цитировании этой статьи сноска на dоі обязательна

\section{Право и политика $12(167) \cdot 2013$}

оспоренных правил, а вторые - наоборот, акцентируют необходимость наличия такого регулирования. Первые должны иметь место в постановления о признании нормы неконституционной, а вторые - в постановления о признании нормы конституционной.

- по периоду действия - на постоянные и временные: первые не ограничены каким-либо сроком действия во времени, а вторые - такой срок знают.

\section{Заключение}

Представленная выше классификация решений и правовых позиций Суда касается лишь дел о нормоконтроле, (как конкретного, так и абстрактного) и актуальна прежде всего для судебной практики, поскольку в них отражается критерий определения обычными судами решений Суда, обладающих обязательным значением, а потому позволяющих непосредственно ссылаться на них в своих решениях.

Между тем, данная классификация еще требует своего развития за счет включения в неё решений Суда по иным категориям дел, кроме дел о нормоконтроле. Между тем, объектом федерального конституционного контроля могут не только нормы права, закрепленные в проверяемых Судом источниках права, но и другие юридические явления:

1) порядок выдвижения обвинения против Президента Российской Федерации в совершении государственной измены или иного тяжкого преступления (глава XV Закона о Конституционном Суде);

2) инициатива проведения референдума Российской Федерации по предложенному вопросу (вопросам) (статья 23, часть 17 статьи 15 Федерального конституционного закона от 28 июня 2004 года № 5-ФКЗ «О референдуме Российской Федерации»).

Отсюда встает вопрос о природе выносимых Судом решений в этих конституционно-судебных производствах, но это тема уже другого повествования.

\section{Библиография:}

1. Алешкова И.А. Правовые позиции Конституционного Суда Российской Федерации: правовая природа и формы их осуществления // Российский судья. - 2013. - № 8. - С. 9.

2. Борисова О.В. Правовые позиции Конституционного Суда Российской Федерации по налоговым спорам: Автореф. дис. ... канд. юрид. наук / 12.00.02, 12.00.14. - М., 2007.
3. Ганичева Е.С. Концепция развития правового регулирования конституционного судопроизводства // Концепции развития российского законодательства / Под ред. Т.Я. Хабриевой и Ю.А. Тихомирова. М.: Эксмо, 2010.

4. Еникеев 3.Д., Васильева Е.Г., Шагеева Р.М., Ежова Е.В. Вопросы уголовного судопроизводства в решениях Конституционного Суда Российской Федерации. - М.: Юрайт, 2011.

5. Жучкова Е.В. Правовые позиции Конституционного Суда Российской Федерации по вопросам уголовного права и уголовного процесса: Автореф. дис. ... канд. юрид. наук / 12.00.02. - М., 2009.

6. Кельзен Г. Судебная гарантия Конституции (конституционная юстиция) (пер. Д.В. Даниленко) // Право и политика. - 2006. - № 8. - С. 5-14; № 9. - С. 5-18.

7. Комментарий к Федеральному конституционному закону «О конституционном Суде Российской Федерации» / Под ред. Г.А. Гаджиева. - М.: Норма; ИНФРА-М, 2012.

8. Петрова Д.В. Правовые позиции Конституционного Суда Российской Федерации по вопросам его деятельности и конституционного судопроизводства: Автореф. дис. ... канд. юрид. наук / 12.00.02. - М., 2008.

9. Сасов К.А. Споры о конституционности налоговых законов6 полномочия Конституционного Суда Российской Федерации: Монография / Под ред. М.Ф. Ивлевой. - М.: Статут, 2006.

10. Шиняева Н. Суды не реагируют на определения KC с позитивным смыслом. URL: http://pravo.ru/ review/view/85691

\section{References (transliteration):}

1. Aleshkova I.A. Pravovye pozitsii Konstitutsionnogo Suda Rossiiskoi Federatsii: pravovaya priroda i formy ikh osushchestvleniya // Rossiiskii sud'ya. - 2013. № 8. - S. 9.

2. Borisova O.V. Pravovye pozitsii Konstitutsionnogo Suda Rossiiskoi Federatsii po nalogovym sporam: Avtoref. dis. ... kand. yurid. nauk / 12.00.02, 12.00.14. - M., 2007.

3. Ganicheva E.S. Kontseptsiya razvitiya pravovogo regulirovaniya konstitutsionnogo sudoproizvodstva // Kontseptsii razvitiya rossiiskogo zakonodatel'stva / Pod red. T.Ya. Khabrievoi i Yu.A. Tikhomirova. M.: Eksmo, 2010. 
DOI: $10.7256 / 1811-9018.2013 .12 .10169$

При цитировании этой статьи сноска на doi обязательна

Судебная власть

4. Enikeev Z.D., Vasil'eva E.G., Shageeva R.M., Ezhova E.V. Voprosy ugolovnogo sudoproizvodstva $v$ resheniyakh Konstitutsionnogo Suda Rossiiskoi Federatsii. - M.: Yurait, 2011.

5. Zhuchkova E.V. Pravovye pozitsii Konstitutsionnogo Suda Rossiiskoi Federatsii po voprosam ugolovnogo prava i ugolovnogo protsessa: Avtoref. dis. ... kand. yurid. nauk / 12.00.02. - M., 2009.

6. Kel'zen G. Sudebnaya garantiya Konstitutsii (konstitutsionnaya yustitsiya) (per. D.V. Danilenko) // Pravo i politika. - 2006. - № 8. - S. 5-14; № 9. - S. 5-18.
7. Petrova D.V. Pravovye pozitsii Konstitutsionnogo Suda Rossiiskoi Federatsii po voprosam ego deyatel'nosti i konstitutsionnogo sudoproizvodstva: Avtoref. dis. ... kand. yurid. nauk / 12.00.02. - M., 2008.

8. Sasov K.A. Spory o konstitutsionnosti nalogovykh zakonov6 polnomochiya Konstitutsionnogo Suda Rossiiskoi Federatsii: Monografiya / Pod red. M.F. Ivlevoi. - M.: Statut, 2006.

9. Shinyaeva N. Sudy ne reagiruyut na opredeleniya KS s pozitivnym smyslom. URL: http://pravo.ru/review/ view/85691 